\title{
HUBUNGAN KONSEPSIONAL ANTARA PERPUSTAKAAN, PENELITIAN, DAN KARYA ILMIAH
}

\author{
Muhammad Muhtar Arifin Sholeh \\ muhtararifin@unissula.ac.id \\ Universitas Islam Sultan Agung Semarang
}

DOI: $10.21580 /$ wa.v6i2.2311

\begin{abstract}
The main purpose of this article is to draw the conceptional relation among library, research, and scientific work. Library is traditionally considered as a place of book collection, a reading room, or 'a small waste room', which show 'a narrow vision'. However, as learning source, library is a place of study, which requires good facility such as providing reading room, complete collection, clear light, good air circulation, etc. It should also be supported by friendly and helpful staff. The relation between research and scientific work is that the report of research should be academically written in national or international journal as a scientific work. In the relation to this, library is a reservoir of collection (printed and non printed collection), including scientific works. In other word, scientific work, like journal or book, should be made as a report of research. Library, research, and scientific work are different from each other, but they can not be separated to each other.
\end{abstract}

Keywords: Library, research, academic work, scientific work

\begin{abstract}
Abstrak
Tujuan utama tulisan ini adalah untuk menggambarkan hubungan konseptional antara perpustakaan, penelitian, dan karya ilmiah. Perpustakaan secara tradisional dianggap sebagai tempat koleksi buku, ruang baca, atau 'ruang sampah kecil', yang menunjukkan 'visi yang sempit'. Namun sebagai sumber belajar, perpustakaan merupakan tempat belajar yang membutuhkan fasilitas yang baik seperti penyediaan ruang baca, koleksi yang lengkap, penerangan yang jernih, sirkulasi udara yang baik, dll. Perlu juga didukung oleh staf yang ramah dan membantu. Kaitan antara penelitian dan karya ilmiah adalah bahwa laporan penelitian harus ditulis secara akademis di jurnal nasional atau internasional sebagai karya ilmiah. Sehubungan dengan hal tersebut, perpustakaan merupakan reservoir koleksi (koleksi cetak dan non cetak), termasuk karya ilmiah. Dengan kata lain, karya ilmiah, seperti jurnal
\end{abstract}


atau buku, harus dijadikan sebagai laporan penelitian. Perpustakaan, penelitian, dan karya ilmiah memang berbeda satu sama lain, namun tidak dapat dipisahkan satu sama lain.

Kata Kunci: Perpustakaan, penelitian, karya akademis, karya ilmiah

\section{A. Pendahuluan}

Kata 'reformasi' berarti 'membuat lebih baik dengan membuang kesalahan'. Tuntutan reformasi telah diwujudkan di berbagai bidang seperti politik, ekonomi, hukum, kesehatan, dan pendidikan. Reformasi di bidang pendidikan dilakukan dalam berbagai hal. Budaya akademik, misalnya, merupakan kebiasaan yang menjunjung tinggi nilai-nilai akademis seperti ilmiah, obyektif, teratur, jujur, dan runtut. Namun demikian, dalam kenyataan budaya akademik belum sepenuhnya diterapkan dan dikembangkan, misalnya masih ada dosen yang tidak obyektif atau tidak jujur dalam penelitian dan masih banyak mahasiswa yang tidak/belum berpikir runtut baik dalam bahasa lisan maupun tulisan.

Pandangan masyarakat terhadap perpustakaan perlu juga direformasi. Perpustakaan dianggap hanya sebagai tempat buku ("gudang buku"), tempat peminjaman buku, dan tempat membaca. Pandangan ini perlu direformasi karena menunjukkan pandangan yang sempit. Perpustakaan tidak hanya sebagai tempat buku tetapi juga sebagai pusat informasi (information centre) yang bertugas mengumpulkan, melestarikan, mengolah, memanfaatkan, dan menyebarluaskan informasi, baik untuk proses belajar mengajar maupun kegiatan penelitian. Perpustakaan jaman now sudah merebak sampai E-Library (electronic library) atau digital library.

\section{B. Pembahasan}

\section{Perpustakaan sebagai Learning Resources}

Perpustakaan dalam konteks makalah ini adalah perpustakaan perguruan tinggi. Perpustakaan perguruan tinggi merupakan bagian integral dari lembaga perguruan tinggi, yang berstatus sebagai Unit Pelaksana Teknis (UPT) di tingkat pusat. Penyelenggaraan perpustakaan perguruan tinggi bertujuan untuk mendukung, memperlancar serta mempertinggi kualitas pelaksanaan program kegiatan perguruan tinggi melalui pelayanan informasi yang meliputi pengumpulan, pelestarian, pengolahan, pemanfaatan, dan penyebarluasan informasi.

Perpustakaan perguruan tinggi, dari berbagai segi, mempunyai banyak fungsi. Dari segi proses pelayanan yang sesuai dengan tujuan tersebut di atas, perpustakaan berfungsi sebagai pusat pelayanan informasi (information service centre) yang mencakup pusat pengumpulan, pelestarian, pengolahan, pemanfaatan, dan penyebarluasan informasi. Segi program kegiatan perguruan tinggi (Tri Darma Perguruan Tinggi) melihat fungsi perpustakaan sebagai pusat pelayanan informasi untuk program pendidikan/pengajaran, 
penelitian, dan pengabdian kepada masyarakat. Dari segi pelaksanaan program tersebut, perpustakaan mempunyai fungsi yang bersifat akademis-edukatif dan administratif-teknis. ${ }^{1}$

Struktur organisasi perpustakaan menunjukkan bahwa perpustakaan mempunyai tiga bagian pokok pelayanan, yaitu pelayanan teknis, pelayanan pemakai, dan pelayanan administrasi. Selain itu, bagian lain dapat ditambahkan seperti bagian pelayanan koleksi bidang ilmu (bidang khusus) dan bagian hubungan luar (kerja sama). Bagian pelayanan teknis adalah bagian yang mengolah koleksi mulai dari pengadaan sampai siap untuk dilayankan (dipinjamkan). Bagian ini meliputi pengadaan, inventarisasi, klasifikasi, katalogisasi, labelisasi, dan perbaikan koleksi yang rusak. Bagian pelayanan pemakai berusaha memberi pelayanan yang berupa peminjaman dan pengembalian koleksi, penelusuran informasi, pencarian koleksi, konsultasi, jasa photo kopi, dan sebagainya. Bagian pelayanan administrasi meliputi pengurusan surat keluar-masuk, keuangan, personalia, saranaprasarana (rumah tangga), dan penyiapan data statistik. ${ }^{2}$

Koleksi perpustakaan perguruan tinggi harus mewujudkan fungsi pendidikan / pengajaran, fungsi penelitian, fungsi referens, dan fungsi umum. Dengan demikian, koleksi perpustakaan harus mampu memenuhi kebutuhan seluruh sivitas akademika perguruan tinggi dan masyarakat sekitar kampus. Koleksi tersebut berupa cetakan maupun bukan cetakan. Koleksi cetakan (printed material) meliputi buku, majalah, koran, skripsi, kamus, ensiklopedi, peta, dan sebagainya. Koleksi bukan cetakan (non printed material) berupa mikro film, kaset (tape / video), piringan hitam, CD ROM (Compact Disc Read Only Memory), dan sebagainya.

Untuk memenuhi kuantitas dan kualitas koleksi serta sarana perpustakaan yang memadai seperti komputer dan mesin photo kopi, perpustakaan perlu mengeluarkan dana yang besar. Agar perpustakaan menunjang program Tri Darma Perguruan Tinggi, biaya yang disediakan hendaknya minimal $5 \%$ dari seluruh biaya perguruan tinggi. ${ }^{3}$

Peran perpustakaan sebagai sumber belajar (learning resources) berarti bahwa perpustakaan menyediakan koleksi yang menjadi sumber materi pelajaran, baik koleksi cetakan maupun bukan cetakan. Dalam hal ini koleksi perpustakaan harus menunjang darma pertama dan kedua dari perguruan tinggi yaitu pendidikan / pengajaran dan penelitian. Oleh karena itu, koleksi perpustakaan harus memenuhi kebutuhan dosen, mahasiswa dan peneliti, serta harus sesuai dengan program studi yang ada di perguruan tinggi. Koleksi merupakan cerminan kebutuhan pemakai perpustakaan yang harus diperhatikan, baik dari segi jumlah maupun mutunya. ${ }^{4}$

Upaya perpustakaan tidak hanya berupa penyediaan koleksi yang memadai tetapi juga usaha pemberian pendidikan bagi para pemakainya (user education). User education (pendidikan pemakai) ialah kegiatan membimbing dan memberi petunjuk kepada para pemakai perpustakaan agar mereka mampu memanfaatkan perpustakaan secara efektif dan

\footnotetext{
${ }^{1}$ Line, Maurice B. Academic Library Management, London: Library Association, 1990

2 Untuk lebih detail, dapat dibaca di buku Sulistyo Basuki, Pengantar Ilmu Perpustakaan, PT Gramedia Pustaka Utama, Jakarta, 1991.

3 Parlinah Moedjono, dkk., Pedoman Umum Perpustakaan Perguruan Tinggi, Sub Proyek Pengembangan Perpustakaan Perguruan Tinggi, Dirjen Dikti, Depdikbud, Jakarta, 1979

${ }^{4}$ Line, Maurice B. Academic Library Management, London: Library Association, 1990
} 
efisien. Beberapa hal yang diberikan pada pendidikan pemakai antara lain mengenal tata kerja perpustakaan dan jenis koleksi, cara menelusuri informasi, menggunakan katalog manual maupun elektronis, dan cara membaca yang efisien. Beberapa faktor yang mempengaruhi keberhasilan program pendidikan pemakai adalah motivasi, tingkat kegiatan pemakai, materi yang mudah dipahami, hubungan guru dan murid, hubungan antar murid, penggunaan sarana dan pra sarana di perpustakaan, dan kesempatan evaluasi.

Selain sebagai learning resources, perpustakaan juga berperan sebagai place of study. Fasilitas perpustakaan hendaknya juga dilengkapi dengan tempat/ruang baca yang tentu saja tersedia meja dan kursi baca. Dalam hal ini kenyamanan ruangan harus dijaga, yang meliputi penerangan yang cukup, sirkulasi udara yang lancar, dan suhu udara yang memadai (di negara panas disediakan Air Condition = AC atau kipas angin, dan di negara dingin diperlukan heater). Jadikan perpustakaan sebagai tempat belajar yang nyaman. Fasilitas lain yang mendukung dua peranan tersebut adalah komputer (komputerisasi perpustakaan) dan mesin photo kopi (jasa photo kopi).

\section{Literatur bagi Para Peneliti}

Literatur yang dimaksud adalah semua sumber informasi ilmiah yang digunakan untuk kegiatan belajar-mengajar dan penelitian, seperti buku, majalah ilmiah, majalah populer, dan surat kabar. Dalam hal ini buku mencakup buku tentang disiplin ilmu tertentu dan buku referensi seperti kamus, ensiklopedi, direktori, buku subyek indeks, buku peta, skripsi, tesis, dan disertasi. Sumber informasi lain yang dapat dipakai para peneliti ialah non printed materials seperti kaset rekorder, kaset video, Compact Disc Read Only Memory (CDROM), Video Compatc Disc (VCD), micro film, dan sebagainya. ${ }^{5}$

Buku adalah karangan seseorang atau lebih tentang suatu ilmu yang terdiri dari beberapa bab, yang masing-masing bab biasanya berkaitan satu dengan lainnya. Buku juga disebut dengan monograph karena ia adalah bentuk karangan dalam satu disiplin ilmu tertentu dan diterbitkan tidak berseri secara rutin namun setiap tahunan. Kelebihan buku adalah penulisannya mendalam, mencakup banyak aspek yang dibahas, dan merupakan satu kesatuan pemikiran yang utuh dalam satu disiplin ilmu. Sedangkan kelemahannya adalah buku akan lebih cepat ketinggalan perkembangan ilmu karena diterbitkan tahunan. Karena pembahasan yang mendalam, seseorang kadang enggan mengkaji buku secara detail. Buku digunakan sebagai sumber teori atau konsep yang diperlukan dalam kegiatan penelitian.

Kamus ialah kumpulan (kompendium) kata-kata yang dijelaskan dalam bahasa yang bersangkutan atau diterjemahkan dalam bahasa asing, yang disusun secara alpabetis. Kamus tersebut adalah kamus bahasa atau leksikon. Sedangkan kamus khusus atau kamus istilah (glosari) merupakan kamus yang berisi istilah-istilah dalam satu disiplin ilmu tertentu yang diberi pengertian. Kamus dapat juga berupa kamus biografi (kamus who's who) yang berisi tentang ringkasan riwayat hidup dan karya-karya tokoh-tokoh tertentu. Dalam kegiatan

${ }^{5}$ Lebih detail dibaca buku Sulistyo Basuki, Teknik dan Jasa Dokumentasi, PT Gramedia Pustaka Utama, Jakarta, 1992 
penelitian kamus digunakan untuk mencari terjemahan kata-kata asing, pengertian secara etimologis maupun terminologis, dan definisi-definisi istilah tertentu.

Ensiklopedi ialah satu buku atau beberapa buku berseri (1 set buku) yang memberi informasi tentang setiap cabang ilmu pengetahuan, atau tentang suatu subyek tertentu, secara singkat yang disusun secara alpabetis. Penjelasan dalam ensiklopedi merupakan penjelasan terminologis yang singkat (seperlunya) yang kadang-kadang disertai gambar. Beberapa contoh ensiklopedi adalah Encyclopaedia Britanica, Encyclopedia Americana, Ensiklopedi Indonesia, Ensiklopedi Islam, Ensiklopedi Hukum Islam, dan sebagainya. Kelebihan ensiklopedi adalah keanekaragaman ilmu, konsep, dan istilah yang disediakan, serta cocok untuk konsep-konsep yang relatif 'statis' (berkembang dalam waktu yang relatif lama). Kelemahannya ialah bahwa ensiklopedia memerlukan revisi yang lama sehingga cepat ketinggalan jaman.

Direktori ialah suatu buku yang menyajikan informasi mengenai orang, organisasi, atau dokumen yang ada pada suatu periode ataupun pada bidang khusus. Direktori biasanya hanya memuat informasi singkat, bahkan hanya daftarnya saja. Beberapa contoh direktori adalah direktori buku yang akan terbit, direktori tesis/disertasi, direktori nama perusahaan, direktori proyek penelitian, direktori nama organisasi kemasyarakatan, dan sebaganya. Kekuatannya adalah direktori memuat banyak nama atau istilah, sedang kelemahannya ialah informasinya sangat singkat seperti hanya menyebut nama dan alamat.

Buku subyek indeks ialah buku yang memuat subyek-subyek (istilah-istilah, terminologies) suatu ilmu tertentu yang disertai dengan sedikit penjelasan, dan biasanya dicantumkan sumber-sumber buku atau majalah yang memuatnya. Walaupun kelemahannya adalah hanya memuat subyek-subyek, buku indeks mempunyai kelebihan, yaitu memuat banyak sumber-sumber tulisan. Contohnya ialah Buku Subyek Indeks (BSI) Kedokteran, BSI Hukum, BSI Ekonomi, dan sebaganya. Hal ini sangat bermanfaat bagi para peneliti.

Buku peta adalah buku yang memuat informasi tentang tempat-tempat di bumi, seperti kota, propinsi, negara, sungai, gunung, laut, selat, danau, tempat ibadah, dan sebagainya, yang sangat bermanfaat bagi para peneliti. Buku peta sangat bermanfaat untuk mengetahui lokasi atau tempat, serta jarak.

Majalah ilmiah ialah kumpulan artikel-artikel ilmiah (karya ilmiah) dalam bidang ilmu tertentu yang diterbitkan secara periodik seperti dua mingguan, bulanan, tiga bulanan, dan sebagainya. Kelebihan majalah ilmiah adalah informasi sangat up to date karena diterbitkan secara periodik mengikuti perkembangan ilmu pengetahuan. Namun, kelemahannya adalah penjelasan yang tidak menyeluruh dan tidak mendalam. Para peneliti paling sering menggunakannya sebagai sumber informasi karena kelebihannya. Sedangkan majalah populer merupakan majalah yang memuat berita-berita, informasi hiburan, pendidikan, ekonomi, dan informasi-informasi ringan (non ilmiah). Sedangkan surat kabar (koran) biasanya memuat berita-berita harian, baik skala lokal, nasional, maupun internasional, namun juga memuat informasi iklan, hiburan, ekonomi, dan informasi ringan lainnya. Koran mempunyai kelebihan, yaitu informasinya sangat up to date (aktual) namun tidak selalu ilmiah. 


\section{Karya Ilmiah}

Bagi peneliti, guru, dosen, atau mahasiswa, menulis karya ilmiah merupakan pekerjaan yang harus dilakukan. Peneliti, guru, dan dosen harus menulis karya ilmiah untuk mengumpulkan kredit poin sebagai kenaikan pangkat/jabatannya, sedangkan mahasiswa harus menulis skripsi sebagai karya ilmiah untuk memenuhi persyaratan sebagai sarjana. Walaupun demikian, tidak semua dari mereka mampu menulis karya ilmiah dengan baik. $\mathrm{Hal}$ ini karena karya ilmiah tidak hanya mencakup pengumpulan ide, tetapi juga penggunaan bahasa yang benar, format (struktur) yang tepat, dan metode serta teknik penulisan yang sesuai dengan peraturan.

Buku, skripsi, disertasi, tesis, dan artikel-artikel di majalah ilmiah (jurnal) dapat dikategorikan sebagai karya tulis ilmiah. Karya ilmiah yaitu karya tulis yang dibuat oleh seorang penulis dengan mengungkapkan ide-idenya yang murni atau yang merujuk pada tulisan ilmiah orang lain, yang berdasarkan pada kaidah-kaidah keilmuan baik tentang penggunaan bahasa, format, maupun teknik penulisan. Namun ada juga yang disebut dengan karya tulis ilmiah populer seperti artikel-artikel di surat kabar. Suatu karya tulis dianggap ilmiah jika ia memenuhi kriteria-kriteria keilmuan. Kriteria tersebut ialah objektif, sistematis, logis, dan menggunakan bahasa formal (bahasa baku).

Menurut Kamus Besar Bahasa Indonesia ${ }^{6}$, objektif berarti mengenai keadaan yang sebenarnya tanpa dipengaruhi pendapat atau pandangan pribadi. Suatu karya ilmiah yang obyektif menitikberatkan pembahasan dari titik pandang obyek yang dikaji, bukan dari titik pandang subyek yang mengkaji (menulis). Dengan demikian penilain terhadap obyek kajian akan konsisten antara penilai satu dengan lainnya. Penilaian yang sama inilah sebagai ciri karya ilmiah yang obyektif.

Sistematis berarti bersifat seperti sistem, yaitu mempunyai bagian-bagian yang tersusun 'rapi' (urut, teratur, dan proporsional) dan berhubungan satu dengan lainnya. Karya ilmiah yang sistematis mempunyai bagian-bagian pembahasan yang berurutan secara logis, tidak tumpang tindih, dan mewakili proporsi judul. Proporsi pendahuluan, isinya, dan kesimpulan harus seimbang.

Karya ilmiah yang logis ialah karya tulis yang mengikuti alur berpikir yang rasional, yang mengikuti patokan-patokan dalam ilmu Logika (ilmu berpikir logis). Dengan kata lain, jalan pikiran isi karya tulis harus sesuai dengan akal sehat. Patokan-patokan berpikir logis antara lain deduksi, induksi, silogisme, qiyas (analogi), klasifikasi logis, dan sebagainya.

Bahasa yang digunakan dalam karya tulis ilmiah adalah bahasa formal (bahasa baku), yaitu bahasa tulis yang sesuai dengan kaidah-kaidah yang ada, seperti dalam pemilihan kata, penggunaan awalan-akhiran, pemakaian huruf besar dan tanda baca, dan sebagainya. Oleh karena itu, penggunaan EYD (Ejaan Yang Disempurnakan) dalam bahasa Indonesia harus diperhatikan. Ciri lain dari bahasa yang ilmiah ialah sederhana (tidak berbelit-belit), logis (dalam struktur kalimat), terhindar dari kata yang bermakna ganda (ambivalensi), sering

${ }^{6}$ Lihat Anton M. Moeliono, dkk., Kamus Besar Bahasa Indonesia, cet. Ke-3, Balai pustaka: Jakarta, 1990 
menggunakan bentuk kalimat pasif (agar tidak terlihat subyektif), tidak menggunakan singkatan (seperti yg, dng, dll, \&), dan mudah dipahami.

Penggunaan bahasa lisan (bahasa 'pasaran') seperti penggunaan kata "semangkin", "bilang", "ngoyoworo", "konyol", "sikon", hendaknya dihindari. Dalam karya tulis ilmiah populer, bahasa 'pasaran' tersebut masih bisa digunakan, karena bahasa tersebut memang populer di masyarakat. Hal ini yang membedakan karya ilmiah murni dengan ilmiah populer.

\section{Topik dan Judul dalam karya Ilmiah}

Langkah pertama untuk menyiapkan sebuah tulisan adalah memilih 'topik' (hendaknya dibedakan dengan 'judul', walaupun kadang-kadang keduanya dianggap sama), yaitu memilih bidang pembahasan yang difokuskan, misalnya pendidikan, ekonomi, politik, kesehatan, hukum, dan sebagainya. Topik dapat dibagi lagi menjadi sub-topik seperti pendidikan informal, ekonomi rumah tangga, politik kerajaan, kesehatan anak, hukum adat, dan lain-lain.

Beberapa hal yang perlu dipertimbangkan dalam pemilihan topik, antara lain : topik harus terjangkau oleh kemampuan penulis, topik harus menarik bagi penulis maupun pembaca, topik harus aktual yang merupakan pembicaraan hangat pada masanya, topik harus mempunyai aspek manfaat bagi penulis maupun pembacanya, dan jangkauan topik tidak terlalu luas (perlu dibatasi).

Untuk memilih topik yang ideal seperti tersebut $\mathrm{di}$ atas, penulis perlu mengumpulkan topik sebanyak-banyaknya dari buku, majalah, koran, atau sumber lainnya. Daftar topik-topik yang ditemukan perlu dibuat. Dalam hal ini, fungsi perpustakaan menjadi sangat penting. Penulis hendaknya memanfaatkan perpustakaan dengan sebaik-baiknya.

Salah satu teknik yang membantu dalam memilih topik ialah teknik brainstorming. Teknik ini berarti berpikir terus untuk mengumpulkan topik, begitu didapat langsung dicatat. Setelah topik terkumpul, penulis segera memilih topik yang sesuai dengan keinginan dan membatasi pembahasan topik. Misalnya, dari sejumlah topik terpilih salah satunya yaitu topik "polusi", topik ini lalu dibatasi apakah topik "polusi udara", "polusi air", atau "polusi suara".

Setelah memilih sebuah topik tertentu, seorang penulis hendaknya menulis judul sebelum mengerjakan karyanya. Judul adalah pernyataan singkat (biasanya berbentuk phrasa/kelompok kata atau klausa/anak kalimat) yang dapat mewakili dari keseluruhan isi karya tulis ilmiah. Judul akan membantu penulis dalam merencanakan penulisan karyanya. Beberapa fungsi judul antara lain sebagai "nama"/"wakil" dari keseluruhan isi karya tulis, sebagai batasan dalam membahas isi karya tulis, sebagai pengarah dalam penulisan, dan sebagai access point (titik pijak) dalam melacak informasi terutama di perpustakaan.

Ada tiga hal yang harus diperhatikan dalam menulis judul, yaitu bentuk judul, ketepatan memilih kata, dan tata bahasa. Bentuk judul karya ilmiah yang lazim digunakan adalah phrasa (kelompok kata) atau klausa (anak kalimat). Misalnya :

Topik : Pendidikan Non-formal 
Judul : Metode-metode Pengajaran dalam Pendidikan Non-formal

(Studi Kasus di Oxford English Course Semarang)

Topik : Politik

Judul : Pengaruh Tingkat Ekonomi terhadap Kesadaran Politik

pada Masyarakat Urban

Topik : Ekonomi

Judul : Faktor-faktor yang mempengaruhi harga di pasaran

Ketepatan memilih kata dalam judul merupakan hal yang penting. Hal ini karena kata yang tepat dalam judul tidak akan membuat para pembaca salah paham (misunderstanding). Kata-kata yang dipakai dalam judul karya ilmiah hendaknya katakata yang baku (bukan bahasa pasaran seperti kata "ngoyoworo", "simbok", "babe", "konyol", "mbludus"), kata-kata yang umum (bukan istilah-istilah yang sulit dipamahi pembaca seperti "canggih", "vegetarian", "unggah-ungguh"), tidak bermakna ganda (seperti kata "bisa", "dapat", "tahu"), bukan singkatan (seperti kata "sikon", "ortu", "telmi"), bukan kata kiasan (seperti "besar kepala", "panjang tangan", "darah biru"), dan berhubungan tepat antara satu kata dengan kata lainnya. Beberapa contoh judul yang tidak tepat dalam penggunaan kata, antara lain :

1. Pengaruh Teknologi "Canggih" terhadap Moral Pemuda

2. Peran "Simbok" dalam Pendidikan Anak

3. Kisah Seorang Anak yang "Panjang Tangan"

4. "Sikon" Guru dan Semangat Mengajar

5. Faktor-faktor "daripada" Kesehatan

Tata bahasa dalam judul karya ilmiah bermaksud menyusun kata-kata dalam judul, termasuk di dalamnya pemilihan kata yang tepat, sehingga sesuai dengan aturan-aturan tata bahasa. Selain itu, kalimat tidak lazim digunakan sebagai judul. Rangkaian kata dalam judul harus menunjukkan hubungan yang tepat sehingga mudah dipahami. Judul-judul yang menyalahi aturan tata bahasa, antara lain:

1. Kehidupan yang "Semangkin" Berat pada Era Globalisasi

2. Studi Komparasi antara Ayam "Bersama" Bebek

3. Dia berkata, "Aku Cinta Kepadamu"

4. Tetapi Paul tetap "Mbludus"

5. Walaupun Dia Orang Kaya

Selain tersebut di atas, judul hendaknya tidak terlalu panjang sehingga sulit untuk diingat-ingat. Judul hendaknya singkat (tetapi tidak terlalu singkat) dan mudah diingat baik oleh penulis maupun pembaca. Jumlah kata dalam judul tidak lebih dari 15 kata; Jika lebih dari 15 kata maka dapat dipakai sebagai sub-judul.

\section{Perpustakaan, Penelitian, dan Karya Ilmiah}

Secara konseptual hubungan perpustakaan, penelitian, dan karya ilmiah adalah sangat erat, bahkan saling bergantung (interdependensi). Perpustakaan berfungsi sebagai sumber belajar (learning resources), yait sebagai sumber informasi ilmiah yang diperlukan dalam penelitian dan pembuatan karya ilmiah. Koleksi perpustakaan, baik dalam bentuik 
buku, majalah ilmiah (jurnal), surat kabar, atau bentuk lainnya, menjadi sumber rujukan teori atau konsep dalam pembuatan karya ilmiah dan dalam tinjauan literatur penelitian lapangan. Hubungan antara perpustakaan dan penelitian adalah bahwa perpustakaan menyediakan informasi ilmiah yang dibutuhkan penelitian, sedangkan hasil penelitian dapat dijadikan sebagai koleksi perpustakaan.

Penelitian, baik dalam bentuk penelitian lapangan (grounded research) maupun penelitian literatur (literary research), merupakan kegiatan ilmiah yang akan menghasilkan karya ilmiah. Hasil penelitian merupakan karya ilmiah yang dapat digunakan untuk pengumpulan angka kredit kepangkatan bagi dosen maupun peneliti, sebagai sumber keuangan, dan sebagai koleksi perpustakaan agar dapat diakses orang lain. Penelitian dan penulisan karya ilmiah membutuhkan literatur yang disediakan oleh perpustakaan. Dengan demikian, tanpa perpustakaan penelitian dan penulisan karya ilmiah tidak akan berjalan dengan lancar. ${ }^{7}$

Literatur yang dimaksud adalah semua sumber informasi ilmiah yang digunakan untuk kegiatan penelitian dan penulisan karya ilmiah, seperti buku, majalah ilmiah, majalah popular, dan surat kabar. Dalam hal ini, buku mencakup buku tentang disiplin ilmu tertentu dan buku referensi seperti kamus, ensiklopedi, direktori, buku subyek indeks, buku peta, skripsi, tesis, dan disertasi. Sumber informasi lain yang dapat dipakai para peneliti ialah non printed materials seperti kaset rekorder, kaset video, Compact Disc Read Only Memory (CDROM), Video Compact Disc (VCD), micro film, dan sebagainya. Seorang peneliti harus mengetahui sumber informasi ilmiah tersebut, yang tentu saja harus sesuai dengan bidang kajiannya.

Dalam hal ini, keahlian melacak (to retrieve - temu balik) informasi akan sangat penting bagi peneliti, baik melacak secara manual maupun elektronis. Hal ini karena pelacakan tersebut akan menentukan apakah peneliti berhasil menemukan data yang benarbenar dibutuhkan atau tidak. Pelacakan informasi elektronis, seperti melalui CD-ROM, LAN (Local Area Network), WAN (Wide Area Network), atau internet, akan menjadi permasalahan tersendiri jika seorang peneliti tidak menguasai teknik dan strategi melacak informasi. Permasalahan tersebut, misalnya, seseorang akan memperoleh records dalam database dengan jumlah yang terlalu banyak atau terlalu sedikit. Jika terlalu banyak maka dia harus menyeleksinya lagi sehingga sesuai dengan kebutuhannya; Namun, jika terlalu sedikit maka dia harus mencari lagi sehingga sesuai dengan jumlah informasi yang diperlukan. Jenis pelacakan informasi elektronis telah menjadi keharusan akibat kemajuan teknologi informasi, sehingga menuntut para peneliti harus menguasainya.

\section{Kesimpulan}

Dengan demikian hubungan antara penelitian dengan karya ilmiah adalah bahwa hasil penelitian harus diungkapkan dalam bentuk tulisan sebagai karya ilmiah, sedangkan karya ilmiah tersebut dapat menjadi acuan bagi para peneliti lain atau penelitian lain;

${ }^{7}$ Lihat Winarno Surakhmad, Pengantar Penelitian Ilmiah, Bandung: Tarsito, 1985, dan Sutrisno Hadi, Metodologi Research (jilid 1), Andi Offset, Yogyakarta, 1993 
Sedangkan hubungan antara karya ilmiah dengan perpustakaan adalah sangat erat, yaitu bahwa karya ilmiah dapat menjadi satu jenis koleksi perpustakaan, sehingga dapat diakses oleh orang yang membutuhkan. Perpustakaan merupakan lembaga yang mengumpulkan, memelihara, dan menyebarkan karya-karya ilmiah. Perpustakaan, penelitian, dan karya ilmiah memang berbeda satu dengan yang lain tetapi mereka tidak dapat dipisahkan satu dengan yang lain.

\section{Daftar Pustaka}

Anton M. Moeliono, dkk., Kamus Besar Bahasa Indonesia, cet. Ke-3, Balai pustaka: Jakarta, 1990

Bennet, Neville \& Clive Carre (ed.), Learning to Teach, Routledge, London, 1993

Bryson, Jo. Effective Library and Information Centre Management, Hants (England) : Gower Publishing Company Limited, 1990

Evans, G. Edward. Management Techniques for Librarians - 2nd. Edition, London : Academic Press, 1983

Hamp-Lyons, Liz \& Karen Berry Courter, Research Matters, Newbury House Publishers, Cambridge, 1984

Line, Maurice B. Academic Library Management, London: Library Association, 1990

Parlinah Moedjono, dkk., Pedoman Umum Perpustakaan Perguruan Tinggi, Sub Proyek Pengembangan Perpustakaan Perguruan Tinggi, Dirjen Dikti, Depdikbud, Jakarta, 1979

Renford, Beverly, and Linnea Hendrickson, Bibliographic Instruction: a Handbook, Neal Schuman, New York, 1980

Rice, James, Teaching Library Use: a Guide for Library Instruction, Greenwood Press, London, 1981

Rowley, Jennifer E., Organizing Knowledge, $2^{\text {nd }}$ edition, Ashgate Publishing Company, Vermont USA, 1992

Shulman, L.S., "Those Who Understand: Knowledge Growth in Teaching” dalam Educational Reseacher No. 15, 1986

-_Knowledge and Teaching: Foundations of the New Reforms" dalam Educational Reseacher No. 57, 1987

Singarimbun, Masri dan Sofian effendi, Metode Penelitian Survai, edisi revisi, LP3ES: Jakarta, 1989

Stueart, Robert D. and Moran, Barbara B. Library Management, Colorado: Libraries Unlimited, 1987

Sulistyo Basuki, Pengantar Ilmu Perpustakaan, PT Gramedia Pustaka Utama, Jakarta, 1991. -, Teknik dan Jasa Dokumentasi, PT Gramedia Pustaka Utama, Jakarta, 1992

Supriyanto, Peran Perpustakaan dalam Pemberdayaan Masyarakat Gemar Membaca, makalah disampaikan pada Muscab IPI Semarang dan Seminar Ilmiah di Semarang, 19 September 1996

Sutrisno Hadi, Metodologi Research (jilid 1), Andi Offset, Yogyakarta, 1993 
Metodologi Research (jilid 2), Yayasan Penerbit Fak. Psikologi UGM, Yogyakarta, 1984

Turabian., Kate L., A Manual for Writer, fifth edition, the University of Chicago Press: Chicago, 1987

Winarno Surakhmad, Pengantar Penelitian Ilmiah, Bandung: Tarsito, 1985 